\title{
PEMBERDAYAAN PEREMPUAN DI PKBM BUNGAEJA KECAMATAN SAMPOLAWA KABUPATEN BUTON SELATAN MELAUI PROGRAM KEAKSARAAN USAHA MANDIRI
}

\author{
Asrul Nazar \\ Fakultas Keguruan dan Ilmu Pendidikan Universitas Muhammadiyah Buton \\ asrulnazar@gmail.com
}

\begin{abstract}
Abstrak
Pemberdayaan Perempuan Dalam Meningkatan Kewirausahaan Usaha Mandiri adalah bentuk layanan program untuk melestarikan keaksaraan dengan memberdayakan masyarakat perempuan melalui kewirausahaan. Mitra kegiatan ini adalah PKBM Bungaeja Kecamatan Sampolawa Kabupaten Buton Selatan. Tujuan utama dari program ini adalah meningkatkan keberdayaan perempuan buta aksara usia 15-59 tahun, melalui peningkatan pengetahuan, keterampilan, sikap, dan berusaha secara mandiri. Dalam hal ini masyarakat diberikan keterampilan guna untuk mengembangkan potensi sumber daya manusia yang ada sehingga masyarakat menjadi berdaya. Pemberdayaan perempuan melalui program Keaksaraan Usaha Mandiri dalam proses kegiatan pembelajarannya menekankan pada pendidikan keterampilan yang berpeluang menjadi suatu bidang usaha yang sesuai dengan minat dan potensi yang dimiliki oleh warga perempuan.
\end{abstract}

Kata Kunci : Pemberdayaan Perempuan, Keaksaraan usaha mandiri 


\section{PENDAHULUAN}

Pendidikan Non Formal adalah upaya untuk meningkatkan sumber daya manusia yang belum dapat terlayani oleh lembaga pendidikan formal pada berbagai tingkatan yang ada, baik karena keterbatasan kemampuan maupun karena keterbatasan kewenangan berdasarkan ketentuan perundang-undangan yang berlaku.

Adapun tujuan pendidikan Non Formal adalah:

1. Melayani warga belajar supaya dapat tumbuh dan berkembang sedini mungkin dan sepanjang hayat guna meningkatkan martabat dan mutu kehidupannya.

2. Membina warga belajar agar memiliki pengetahuan, keterampilan dan sikap mental yang diperlukan untuk mengembangkan diri, kesiapan bekerja atau melanjutkan ke jenjang pendidikan yang lebih tinggi.

3. Memenuhi kebutuhan belajar masyarakat yang tidak dapat dipenuhi pada pendidikan formal. Dengan demikian pendidikan Non Formal dapat menyediakan berbagai layanan pendidikan untuk semua dan sepanjang hayat sesuai kebutuhan masyarakat.

Menurut Undang-Undang Nomor 32 tahun 2003 tentang Sistem Pendidikan Nasional, bahwa pendidikan diselenggarakan melalui tiga jalur, yaitu jalur pendidikan informal, jalur pendidikan formal, dan jalur pendidikan non formal. Pendidikan non formal diselenggarakan bagi warga masyarakat yang membutuhkan layanan pendidikan secara khusus dan berfungsi sebagai pengganti, penambah dan atau pelengkap pendidikan formal dalam rangka mendukung pendidikan sepanjang hayat.

Pendidikan non formal berfungsi untuk mengembangkan kemampuan peserta didik melalui pengetahuan dan keterampilan fungsional serta mengembangkan sikap dan mempunyai kepribadian profesional yang diaplikasikan melalui pendidikan kecakapan hidup (life skill) pendidikan anak usia dini, pendidikan pemberdayaan perempuan, pendidikan keaksaraan, pendidikan kesetaraan, serta pendidikan lain yang ditujukan untuk mengembangkan kemapuan peserta didik. Dalam rangka pemberantasan buta aksara dan meningkatkan pendapatan masyarakat, telah dilakukan untuk menguasai ragam keaksaraannya dan diarahkan untuk menguasai ragam keaksaraan melalui program pemberdayaan perempuan melalui program keaksaraan usaha mandiri.

Keaksaraan usaha mandiri adalah kemampuan membaca, menulis, dan berhitung, mendengarkan dan berbicara untuk mengkomunikasikan teks lisan dan tulisan dengan menggunakan aksara dan angka dalam bahasa Indonesia. Keaksaraan usaha mandiri merupakan kemampuan atau keterampilan dasar usaha yang dilatihkan melalui pembelajaran produktif dan keterampilan bermatapencaharian yang dapat meningkatkan keaksaraan dan penghasilan, baik secara perorangan maupun kelompok sebagai salah satu upaya penguatan keaksaraan sekaligus pengentasan kemiskinan.

Program Keaksaraan Usaha Mandiri (KUM) merupakan kegiatan peningkatan kemampuan keberaksaraan bagi warga belajar yang telah 
mengikuti dan atau mencapai kompetensi keaksaraan dasar, melalui pembelajaran keterampilan usaha (kewirausahaan) yang dapatmeningkatkan produktivitas warga belajar, baik secara perorangan maupun kelompok sehinggga diharapkan dapat memiliki mata pencaharian dan penghasilan dalam rangka peningkatan taraf hidupnya (Hening Ratri, 2015).

Tujuan dari Keaksaraan Usaha Mandiri adalah meningkatkan partisipasi perempuan berusia 15-59 tahun yang berkeaksaraan rendah dalam mengikuti kegiatan keaksaraan usaha mandiri. Meningkatkan keberdayaan penduduk usia 15-59 tahun yang berkeaksaraan rendah melalui peningkatan pengetahuan, sikap, dan keterampilan serta berusaha secara mandiri. Memelihara dan melestarikan tingkat keberaksaraan penduduk melalui kegiatan ragam keaksaraan.

Keaksaraan usaha mandiri adalah model pembelajaran pemberantasan dan penguatan keaksaraan warga belajar dengan menggabungkan muatan materi pokok membaca, menulis, berhitung yang terangkum dalam keaksaraan usaha mandiri, dengan materi penunjang yaitu keterampilan fungsional berbasis pada minat, kebutuhan dan potensi pasar/peluang pasar (Nurwahidah, n.d.).

Keaksaraan Usaha Mandiri berupa pelatihan membaca, menulis, berhitung dan mendengarkan. Kondisi seperti ini akan diberikan sentuhan akademik dalam bentuk kecakapan hidup (life skill) berupa keterampilan ekonomi kreatif berupa kerajinan untuk meningkatkan pendapatan.
Sekarang perempuan dituntut aktif secara ekonomi, meskipun disisi lain ada juga tuntutan agar perempuan yang berkeluarga dapat menghasilkan uang tanpa mengganggu fungsinya sebagai istri dan ibu rumah tangga. Saat ini fenomena perempuan bekerja bukan lagi barang aneh dan bahkan dapat dikatakan sudah merupakan tuntutan bagi perempuan untuk berpartisipasi dalam dunia kerja, yang dapat menaikkan harkat perempuan, yang sebelumnya selalu dianggap hanya sebagai pengurus anak, suami dan rumah tangga semata-mata (Nainggolan, 2013).

Perempuan sebagai warga negara yang memiliki hak dan kewajiban yang sama dengan laki-laki, namun dalam bidang pendidikan dan ekonomi, banyak perempuan Indonesia yang tidak memiliki kemampuan memperoleh peluang kerja karena keterbatasan atau tidak bisa mengolah potensi yang ada pada dirinya maka perlunya pemberdayaan perempuan (Karwati, 2017).

Pemberdayaan merupakan salah satu wadah yang dijadikan sebagai upaya untuk memberikan wahana bagi masyarakat dalam memenuhi akan kebutuhan warga belajar berupa pengetahuan dan keterampilan yang berkaitan bagi kehidupan yang lebih baik di dalam kehidupan keluarga dan masyarakat (Karwati, 2017).

Pengembangan kewirausahaan untuk meningkatkan ekonomi masyarakat melalui pendidikan non-formal. Program pendidikan non-formal yang pada dasarnya adalah proses pemberdayaan masyarakat diharapkan menjadi titik awal untuk meningkatkan 
kesejahteraan

masyarakat.

Upaya

mengatasi persoalan tersebut, diperlukan model Pemberdayaan Masyarakat untuk meningkatkan Kewirausahaan Usaha Mandiri dan pada akhirnya mampu meningkatkan status sosial ekonominya.

Menciptakan wirausaha (Entrepreneurship) yang tangguh tidaklah mudah, karena diperlukan prasyarat-prasyarat tertentu, di antaranya adalah mampu menatap masa dengan lebih baik, memiliki orientasi kreatif dan perspektif (Mulyono, 2015).

Dengan demikian maka sebaiknya dalam pengembangan sumber daya perempuan sebaiknya diarahkan untuk membentuk manusia yang (1) memiliki motivasi dan etos kerja yang tinggi, (2) menguasai banyak ilmu dan keterampilan, (3) memiliki sikap mental yang konsisten yang diwujudkan dalam komitmennya pada bidang pekerjaan tertentu (profesional), (4) memiliki semangat dan kemampuan bersaing (kompetitif), dan (5) memiliki budaya yang didasari pada nilai-nilai agama dan humanisme (Nurwahidah, n.d.).

Pusat Kegiatan Belajar Masyarakat Bungaeja mempunyai tugas untuk melaksanakan pendidikan non-formal dalam rangka menunjang kelancaran tugas Dinas Pendidikan Kabupaten Buton Selatan sebagai pelaksanaan program PKBM Bungaeja harus mampu melayani semua kebutuhan belajar warga masyarakat di daerah masing-masing. Dengan sarana dan ketenagaan yang ada dan bertekad untuk melayani secara maksimal seluruh program pendidikan non-formal seperti pendidikan anak usia dini, pendidikan keaksaraan, pendidikan kesetaraan, pendidikan kecapan hidup dan lain-lain.

Pada PKBM Bungaeja Kecamatan Sampolawa Kabupaten Buton Selatan peserta didiknya adalah perempuan putus sekolah serta tidak memiliki keterampilan. Melihat situasi permasalahan tersebut di atas maka peneliti melaksanakan kegiatan Pengabdian Kepada Masyarakat (PKM) di PKBM Bungaeja Kecamatan Sampolawa Kabupaten Buton Selatan.

Kegiatan PKM ini dilaksanakan oleh dosen Universitas Muhammadiyah Buton. Kegiatan pengabdian ini tidak hanya sebagai perwujudan tanggung jawab dosen untuk melaksanakan tanggungjawab dalam hal tridharma perguruan tinggi yang dilaksanakan rutin setiap tahun pada masyarakat, melainkan juga sebagai sebuah kegiatan yang memberikan pengalaman kepada masyarakat khusunya perempuan. Kegiatan ini tentunya akan menambah wawasan sekaligus melengkapi keterampilan dosen.

Kegiatan Pengabdian Kepada Masyarakat (PKM) ini diselenggarakan di PKBM Bungaeja Kecamatan Sampolawa Kabupaten Buton Selatan, adapun tujuan dari pengabadian kepada masyarakat ini ialah:

1. Memberikan bekal pengetahuan kepada peserta didik Keaksaraan Usaha Mandiri

2. Memberikan bekal keterampilan kepada peserta Keaksaraan Usaha Mandiri melalui pembelajaran keterampilan. 


\section{METODE PELAKSANAAN}

Metode yang digunakan merupakan metode pemberdayaan masyarakat yang terdiri dari Ceramah, Curah Pendapat, Diskusi. Adapun populasinya adalah peserta didik PKBM Bungaeja khususnya perempuan. Kegiatan pengabdian ini dilaksanakan dalam bentuk penyuluhan dengan pendampingan, kegiatan ini dilaksanakan pada tanggal 5 Januari 2020. Adapun output yang menjadi target dalam pengabdian ini adalah Peserta didik
PKBM Bungaeha program Keaksaraan Usaha Mandiri mempunyai bekal pengetahuan dan keterampilan.

\section{HASIL DAN PEMBAHASAN}

Kegiatan Pengabdian Kepada Masyarakat ini dilaksanakan di PKBM Bungaeja Kecamatan Sampolawa Kabupaten Buton Selatan. Adapun tahapan pelaksanaan kegiatan Pengabdian Pada Masyarakat secara lengkap dapat dilihat pada Tabel berikut:

Tabel 1. Tahapan Kegiatan Pengabdian

\begin{tabular}{|c|l|l|l|}
\hline No & \multicolumn{1}{|c|}{ Tahapan Kegiatan } & \multicolumn{1}{|c|}{$\begin{array}{c}\text { Metode yang } \\
\text { Digunakan }\end{array}$} & \multicolumn{1}{c|}{ Keterangan } \\
\hline 1 & Survei dan Penetapan Wilayah Mitra & Pertemuan dan diskusi & $\begin{array}{l}\text { Tim PKM, dan Ketua } \\
\text { PKBM Bungaeja }\end{array}$ \\
\hline 2 & $\begin{array}{l}\text { Melakukan koordinasi penyelenggaraan } \\
\text { kegiatan Pengabdian Kepada Masyarakat }\end{array}$ & Pertemuan dan diskusi & $\begin{array}{l}\text { Tim PKM, Ketua PKBM } \\
\text { Bungaeja, dan peserta didik }\end{array}$ \\
\hline 3 & $\begin{array}{l}\text { Kegiatan Pengabdian pada masyarakat } \\
\text { dilaksanakan melalui penyuluhan dan } \\
\text { pelatihan }\end{array}$ & Pertemuan dan diskusi & $\begin{array}{l}\text { Tim PKM dan peserta didik } \\
\text { PKBM Bungaeja }\end{array}$ \\
\hline
\end{tabular}

Proses pelaksanaan kegiatan yang telah dilakukan dalam rangka meningkatkan Keaksaraan Usaha Mandiri di PKBM Bungaeja memberikan pendidikan keaksaraan usaha mandiri untuk meningkatkan kemampuan atau keterampilan dasar usaha yang dilatihkan melalui pembelajaran produktif dan keterampilan bermatapencaharian yang dapat meningkatkan keaksaraan dan penghasilan, baik secara perorangan maupun kelompok sebagai salah satu upaya penguatan keaksaraan sekaligus pengentasan kemiskinan.

Uraian kegiatan pemberdayaan perempuan dalam meningkatkan keaksaraan usaha mandiri yang dilaksanakan adalah sebagai berikut:

\section{Sosialisasi}

Sosialisasi dalam meningkatkan keaksaraan usaha mandiri merupakan kegiatan yang sangat penting, hal tersebut karena keaksaraan pada umumnya masih asing bagi sebagian masyarakat yang berada pada kawasan atau daerah tertinggal dan terkebelakang atau daerah terpencil. Sosialisasi dimaksudkan untuk memperkenalkan program Keaksaraan Usaha Mandiri kepada masyarakat dan sasaran terkait dengan pelaksanaannya. Khusus kepada warga peserta didik PKBM Bungaeja disosialisasikan bagaimana bentuk kegiatannya, cara pelaksaaannya, siapa yang melaksanakan, berapa lama berlangsung, apa saja yang menjadi 

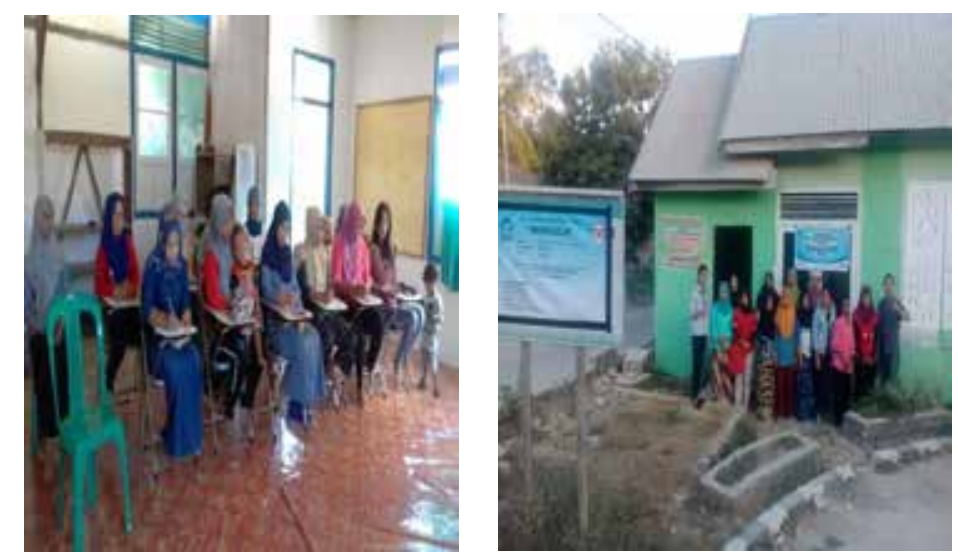

Gambar 1. Sosialisasi kegiatan PKM Tentang Pemberdayaan Perempuan Melalui Program Keaksaraan Usaha Mandiri

hak dan kewajiban peserta didik dalam mengikuti kegiatan PKM. Sosialisasi dilaksanakan beberapa kali, agar kegiatan Keaksaraan Usaha Mandari dapat dipahami dan dimengerti oleh masyarakat sebagai sasaran.

\section{Pelaksanaan Kegiatan}

Dalam melaksanakan kegiatan pemberdayaan perempuan melalui program keaksaraan usaha mandiri pertam-tama dilakukan persiapan pembelajaran, kegiatan ini meliputi:

a. Penyiapan rencana dan jadwal kegiatan yang dituangkan dalam Acuan Pelaksanaan.

b. Sosialisasi dan koordinasi pelaksanaan kegiatan.

Setelah itu Pelaksanaan Pembelajaran, untuk pelaksanaan pembelajaran mengacu pada Standar Kompetensi Keaksaraan Usaha Mandiri. Setiap kelompok belajar minimal 10 peserta didik.

Setelah itu penyelenggaraan bersama Tim PKM dan peserta didik, membuat kesepakatan (kontrak belajar) dan kegiatan pembelajaran.
Kontrak belajar mencakup jadwal, tempat, waktu dan tata tertib. Kemudian, pelaksanakan kegiatan pembelajaran/keterampilandasarusaha yang dilakukan secara terstruktur. Kegiatan tersebut mencakup peserta mengungkapkan keinginan berusaha berdasarkan minat dan potensi yang tersedia. Setelah memetakan minat, peserta didik kemudian mempraktikkan sebuah keterampilan yang berpeluang menjadi bidang usaha dan menyusun rancangan usaha. Tahapan selanjutnya adalah mengembangkan usaha mandiri yang telah disusun dengan merancang dan mengelola biaya, mengidentifikasi risiko-risiko yang mungkin timbul dan mempengaruhi laba rugi usaha, memahami strategi pemasaran, mengenali kekuatan pesaing dalam pasar produk yang dikembangkan, menjalin kemitraan, dan menjaga kelangsungan usaha yang dikembangkan.

Materi dalam kegiatan PKM pemberdayaan perempuan melaui program keaksaraan usaha mandiri yaitu: 
Tabel 2. kegiatan PKM pemberdayaan perempuan melaui program keaksaraan usaha mandiri

\begin{tabular}{|c|c|c|}
\hline Metode & $\cdot$ & Ceramah, Curah Pendapat, Diskusi \\
\hline $\begin{array}{l}\text { Kegiatan } \\
\text { Pembelajaran }\end{array}$ & & $\begin{array}{l}\text { Kegiatan Pendahuluaan. } \\
\text { 1. Pembukaan dan salam; } \\
\text { 2. Apersepsi materi (memberikan gambaran materi yang akan dibahas/dipelajari); } \\
\text { 3. Pemberian motivasi kepada peserta didik agar mereka memiliki kesiapan belajar; } \\
\text { 4. Pemberian petunjuk/acuan belajar kepada warga belajar. } \\
\text { Kegiatan Inti Pembelajaran. } \\
\text { 1. Menjelasakan jenis bidang-bidang usaha yang berpeluang untuk dikembangkan; } \\
\text { 2. Curah pendapat, tanya jawab dan penjelasan minat dan keterampilan yang dimiliki } \\
\text { warga belajar; } \\
\text { 3. Diskusi dan tanya jawab bidang usaha yang sesuai dengan minat dan keterampilan } \\
\text { warga belajar yang memungkinkan untuk dikembangkan; } \\
\text { 4. Menjelaskan cara menentukan pilihan jenis bidang usaha yang sesuai dengan minat } \\
\text { dan keterampilan; } \\
\text { 5. Diskusi memilih jenis usaha yang sesuai minat dan keterampilan warga belajar. } \\
\text { Kegiatan Penutup } \\
\text { 1. Diskusi, curah pendapat, dan tanya jawab pelaksanaan usaha sesuai minat dan } \\
\text { keterampilan warga belajar; } \\
\text { 2. Diskusi dan curah pendapat untuk memutuskan jenis usaha yang akan } \\
\text { dikembangkan baik secara individu maupun berkelompok; } \\
\text { 3. Diskusi, curah pendapat, dan tanya jawab menyusun persiapan - persiapan } \\
\text { pelaksanaan kegiatan usaha sesuai minat dan keterampilan usaha; } \\
\text { 4. Menyimpulkan kesepakatan tentang jenis usaha yang akan dikembangkan. }\end{array}$ \\
\hline Sumber Belajar & & Buku-buku pengembangan dan pemilihan usaha. \\
\hline Materi belajar & $:$ & $\begin{array}{l}\text { 1. Minat dan keterampilan usaha yang dimiliki warga belajar; } \\
\text { 2. Mengidentifikasi bidang-bidang usaha yang berpotensi untuk dikembangkan; } \\
\text { 3. Bidang-bidang usaha yang sesuai dengan minat dan keterampilan warga belajar; } \\
\text { 4. Teknik memilih bidang usaha yang sesuai minat dan keterampilan; } \\
\text { 5. Perencanaan kegiatan usaha. }\end{array}$ \\
\hline
\end{tabular}

\section{KESIMPULAN}

Berdasarkan kegiatan pengabdian tentang pemberdayaan perempuan melaui program keaksaraan usaha mandiri, mulai dari awal pelaksanaan yakni survei penetapan mitra, pelaksanaan kegiatan penyampaian materi pemberdayaan perempuan dalam meningkatkan keaksaraan usaha mandiri, dapat disimpulkan bahwa kegiatan pengabdian seperti ini sangat dinantikan oleh peserta didik khususnya perempuan usia 15-49 tahun di PKBM Bungaeja dalam upaya pengembangan dan pemilihan usaha. Perempuan usia 15-49 tahun yang menjadi target sasaran kegiatan pengabdian ini sangat antusias mengikuti kegiatan penyampaian materi melalui ceramah dan diskusi.

\section{DAFTAR PUSTAKA}

Hening Ratri. (2015). Pelaksanaan Program Keaksaraan Usaha Mandiri (Kum) Dengan Pemberdayaan Masyarakat Di Pkbm Handayani Dea Baureno Kecamatan Baureno Kabupaten Bojonegoro. J+Plus Unesa, 4(1), 1-11. 
https://jurnalmahasiswa.unesa.ac.id/ index.php/jurnal-pendidikan-luarsekolah/article/view/13236

Karwati, L. (2017). Pemberdayaan Perempuan Melalui Pelatihan Woman Empowerment Through Entrepreneurs Training. Jurnal Ilmiah Visi PGTK PAUD Dan Dimas, 12(1), 45-52. https://media.neliti.com/ media/publications/259938-pemberdayaanperempuan-melalui-pelatihan-5d1ad68b.pdf
Nainggolan, D. Y. (2013). PEMBERDAYAAN DAN PENGEMBANGAN WIRAUSAHA PEREMPUAN MUDA PADA RUMAH TANGGA MISKIN DI KECAMATAN MEDAN DELI KOTA MEDAN. JURNAL ILMU SOSIAL-FAKULTAS ISIPOL UMA, 6(April), 14-29.

Nurwahidah, H. L. S. (n.d.). PEMBERDAYAAN PEREMPUAN MELALUI PEMBELAJARAN LITERASI BERORIENTASI KEAKSARAAN USAHA MANDIRI. Jurnal Ilmiah Program Studi Pendidikan Bahasa Dan Sastra Indonesia, 55-67. 